\title{
Exchange Rate Volatility and Trade:
}

\section{Evidence from Monthly Trade Data}

Authors:

Filiations:
Florian Johannsen ${ }^{\mathrm{A}}$

Inmaculada Martinéz-Zarzoso ${ }^{B, A}$

${ }^{A}$ Georg-August Universität Göttingen, Germany

${ }^{\mathrm{B}}$ Universitat Jaume I,Spain

JEL classification: F1, F3

Contact Information

Address: Florian Johannsen

Chair of Economic Theory and Development Economics

Platz der Göttinger Sieben 3

37073 Göttingen

Germany

Email: florian.johannsen@wiwi.uni-goettingen.de 


\section{Table of Contents}

$\begin{array}{ll}\text { Introduction } & 1\end{array}$

Literature $\quad 2$

Data $\quad 3$

Measuring Volatility $\quad 4$

$\begin{array}{ll}\text { Empirics } & 5\end{array}$

$\begin{array}{lr}\text { Results } & 7\end{array}$

Findings $\quad 8$

$\begin{array}{lr}\text { Conclusion } & 9\end{array}$

Bibliography I

Appendix IV

\section{Index of Tables}

Table 1: Coverage $\quad 3$

Table 2: BEC Categories $\quad 4$

Table 3: Variable $\quad 6$

Table 4: Control Variables $\quad 7$

Table 5: Aggregate regressions by time period IV

Table 6: Regression results by type of goods $\quad \mathrm{V}$ 


\section{Introduction}

The End of the Bretton Woods system in the early 1970's and the adoption of a floating exchange rate regime in 1973 raised the question how the resulting increase in exchange rate volatility causes exchange rate risk and affects international trade and welfare. The EMU and the introduction of the EURO, associated with the abolition of several European currencies, lead to a huge debate among economists about the effects on trade.

Very recently, the global financial crisis as the catalyst of the debt crises and massive central bank interventions especially in Europe and the U.S. has increased exchange rate volatility again and brought the topic back on the agenda.

In the light of the recent events, especially the case of Europe and the Euro is worth a second glance. The question whether or not giving up your domestic currency and thereby eliminating exchange rate volatility with various other countries is boosting trade significantly is a very relevant question for many Central and Eastern European countries. Countries like Poland postponing their accession to the Euro is a strong indicator for that.

As theoretical predictions concerning the impact of uncertainty induced by exchange rate volatility on trade have no unambiguous results and often are contradictory, empirical investigations are expedient to prove or overhaul the various existing theories.

The aim of this paper is to provide further evidence literature by presenting several novelties with respect to prior research. Higher frequency trade data is used to take into account the short term effects of volatility. Disaggregated trade data is used to deal with differences among product categories, especially between agricultural and manufactures and intermediates and final products. In contrast to many other studies, probable econometric problems including zero trade values and country specific effects are taken care of.

Furthermore, the recent development including the financial crisis and various countries joining the $\mathrm{EU}$ is covered, yielding additional findings and policy implications.

Our results show a positive effect on trade for a EU membership, but unambiguous results for a Euro membership and exchange rate volatility. For the latter two we found the effects to vary for different industries and time periods. We also found different effects for the intensive and extensive margin of trade. 


\section{Literature}

There are several literature survey papers available that provide a good overview of the topic (Bahmani-Oskooee \& Hegerty, 2007; Côté, 1994; McKenzie, 1999; Ozturk, 2006).

As mentioned before, theoretical studies have shown mixed effects. While most describe negative effects for an increase of exchange rate volatility on trade due to rising levels of uncertainty (e.g. Clark (1973)), some describe possible positive or ambiguous effects (Franke, 1991; Sercu \& Vanhulle, 1992). The latter may depend on the aggregate exposure to risk (Viaene \& de Vries, 1992) and the type of shocks firms are exposed to (Barkoulas et al. 2002). Broll \& Eckwert (1999)argue that volatility is increasing the value of a firm's options to export by increasing the potential gains from trade.

To reduce the risk of exchange rate fluctuations, in theory firms can hedge via forward markets. But those may not sufficiently developed (Baron, 1976) or are costly and imperfect for small firms as they are more likely to face liquidity constraints (Baldwin \& Krugman, 1989). Thus, Wei (1999) finds no empirical evidence for the hypothesis that the availability of hedging instruments reduces the impact of exchange rate volatility on trade.

The empirical findings reflect the unambiguous theoretical results. One reason is probably the sample choice as countries tend to react differently to exchange rate shocks (Baum et al. 2004). Another reason might be that exports for different products react differently.

In general, studies employing the gravity equation in international trade models are more likely to find a negative relationship between exchange rate volatility and trade (e.g. Dell'Ariccia, 1999; Rose, 2000; Tenreyro, 2007). However, Clark et al. (2004) argue that most of these findings are not robust to a more general specification of the gravity equation that embodies the recent theoretical advances.

Investigating the results of the empirical literature for the years 1978 to 2003, Ćorić \& Pugh (2010) find that the empirical literature on exchange rate variability and trade reveals a modestly negative relationship with pronounced heterogeneity.

What could be responsible for at least a part of the mixed results in the literature is the aggregation problem (e.g. Wang \& Barrett (2007)). It is caused by the use of not decomposed but aggregated data in most studies. Different Industries can be expected to be affected to a different extent by uncertainty caused by exchange rate fluctuations and thus to react differently in scale 
and direction. Theses differences can be the timeframe of contracting, the availability and costs of hedging instruments or differences in the responsiveness to price changes in different industries. Furthermore, the currency of contracting, the openness to international trade, the degree of homogeneity or the storability of goods might have an significant impact. Thus, it is important to take industry related differences into account and to control for them.

To evaluate the real consequences for economies it is also important to determine whether volatility by increasing uncertainty has an impact on industrial production and welfare. Barkoulas et al. (2002) state that in open economies fluctuations of trade flows can significantly impact the variability of the overall level of economic activity resulting in financial sector illiquidity, reductions in real output or heightened inflationary pressures. Bacchetta \& van Wincoop (2000) find evidence that the exchange rate regime has no influence on trade and the more trade does not have to lead to higher levels of welfare.

\section{Data}

We have build a dataset with monthly bilateral trade for 28 countries for the 15 years from January 1996 till December 2010. The countries included are EU countries and their mayor trading partners (Table 1$)^{1}$

Table 1: Coverage

\begin{tabular}{|c|c|c|c|c|}
\hline \multicolumn{5}{|c|}{ Countries } \\
\hline Austria & France & Italy & Portugal & Switzerland \\
\hline Belgium & Germany & Japan & Russia & Turkey \\
\hline Czech Republic & Greece & Luxembourg & Slovakia & United Kingdom \\
\hline Denmark & Hungary & Netherlands & Slovenia & USA \\
\hline Estonia & India & Norway & Spain & \\
\hline Finland & Ireland & Poland & Sweden & \\
\hline
\end{tabular}

1 China as the only missing country of the eight biggest EU trading partners and the EU-members Bulgaria, Cyprus, Lithuania, Latvia, Malta and Rumania were supposed to be part of this investigation, but could not be included due to problems with data availability. Data for Greece is missing in the years from 1996-1999 and Russia from 19962002. 
The nominal monthly bilateral trade data is disaggregated according to the BEC classification ${ }^{2}$ (Table 2) with Eurostat being the source. Unfortunately Eurostat does not deliver data on bilateral trade between two non-EU members.

Nominal GDP data from the OECD database was used ${ }^{3}$ and nominal GDP per capita was constructed using population data from the World Development Indicators (WDI).

Table 2: BEC Categories

\begin{tabular}{cl}
\hline BEC Code & \\
\hline $111^{2}$ & Food and beverages / primary / mainly for ind ustry \\
$112^{3}$ & Food and beverages / primary / mainly for household consumption \\
$121^{2}$ & Food and beverages / processed / mainly for industry \\
$122^{3}$ & Food and beverages / processed / mainly for household consumption \\
$210^{2}$ & Industrial supplies n.e.s. / primary \\
$220^{2}$ & Industrial supplies n.e.s. / processed \\
$310^{2}$ & Fuels and lubricants / primary \\
321 & Fuels and lubricants / processed / motor spirit \\
$322^{2}$ & Fuels and lubricants / processed / other \\
$410^{1}$ & Capital goods (except transport equipment) \\
$420^{2}$ & Capital goods / parts and accessories \\
510 & Transport equipment and parts and accessories thereof / passenger motor cars \\
$521^{1}$ & Transport equipment and parts and accessories thereof / other / industrial \\
$522^{3}$ & Transport equipment and parts and accessories thereof / other / non-industrial \\
$530^{2}$ & Transport equipment and parts and accessories thereof / parts and accessor. \\
$610^{3}$ & Consumer goods n.e.s. / durable \\
$620^{3}$ & Consumer goods n.e.s. / semi-durable \\
$630^{3}$ & Consumer goods n.e.s. / non-durable \\
700 & Goods not elsewhere specified \\
\hline
\end{tabular}

Superscript denotes whether category is ${ }^{1}$ capital good, ${ }^{2}$ intermediate or ${ }^{3}$ consumption good

To construct the volatility measure, we used Daily nominal middle exchange rates by Datastream from the WM Company/Reuters. ${ }^{4}$ Variables identifying specific geographical or cultural links taken are from the CEPII datasets.

\section{Measuring Volatility}

The measurement of exchange rate volatility has been conducted in many different ways following the latest econometric advancements. Most approaches have in common to measure the

2 A thorough description of the BEC classification is available by the United Nations Department of Economic and Social Affairs (2007).

3 OECD GDP data is only available on a quaterly basis. Monthly GDP data was derived by using the DENTON procedure for STATA by Baum \& Hristakeva (2001).

4 This rate is the midpoint between the bid rate and the offered rate. 
variance, but differ in the implementation. Examples are standard deviation of a rate of change or a moving standard deviation. $\mathrm{ARCH}$ and $\mathrm{GARCH}$ as measure of volatility have gained popularity. They model the variance of the disturbance term for each period as a function of the errors in the previous periods. The introduction of new and more sophisticated measures has however not changed the results significantly (Ćorić \& Pugh, 2010).

Another important question is whether the volatility of the nominal or the real exchange rate is to be used. While as an advantage the real exchange rate captures the true relative price of the good, it also captures variation in the price levels, what is not desirable. Many studies use both exchange rates and compare the results. The differences they find are usually very small. ${ }^{5}$

We are employing the standard deviation of the first difference of logarithms, that has been used in various studies before (e.g. Clark et al. (2004)). If the exchange rate is on a consistent trend, which apparently could be forecasted and consequently would not be a source of uncertainty, the measure has the ability that it will equal zero.

To avoid bias from changes in price levels via spurious correlation, we use nominal exchange rates. The measure is constructed as a short term volatility measure with bilateral exchange rates from the past six month. Different to many other studies, we are constructing our exchange rate volatility measure with daily exchange rates which allow more precise measures than monthly values.

\section{Empirics}

We want to estimate the effect of our exchange rate measure and the dummies for EU and Euro membership on exports by following the literature that employs the standard gravity equation in international trade (e.g. Rose (2000)).

To see whether there is an effect for the aggregated data or rather a change over time we conduct an estimation on the whole dataset separated into two time periods: 1996-2003 and 2004-2010. Then to check whether different goods react differently on the investigated effects, we conduct an estimation for three groups ${ }^{6}$ : capital goods, intermediates and consumption goods.

5 A very profound comparison of the effects real and nominal exchange rate volatility on exports was conducted by Cotter \& Bredin (2011) finding that magnitude and direction are not changing, while timing effects can be different.

6 The groups were build following the classification of the United Nations Department of Economic and Social Affairs from 2007 (Table 2). 
First we are conducting country and year fixed-effects and random-effects regressions on the log of the volume of bilateral exports. Therefor we are estimating the following equation:

$$
\begin{gathered}
\ln X_{i j t}=\beta_{0}+\beta_{1} \ln \left(Y_{i t}\right)+\beta_{2} \ln \left(Y_{j t}\right)+\beta_{3} \ln \left(\frac{Y_{i t}}{\text { Pop }_{i t}}\right)+\beta_{4} \ln \left(\frac{Y_{j t}}{\text { Pop }_{j t}}\right)- \\
\beta_{5} \ln \left(\text { Distance }_{i j}\right)+\beta_{6} \text { EU }_{i j t}+\beta_{7} \text { Euro }_{i j t}+\beta_{8} \text { Border }_{i j}+\beta_{9} \text { Language }_{i j}- \\
\beta_{10} \text { Landlocked }_{i}+\beta_{11} \text { Island }_{i}+\beta_{12} \text { Colony }_{i j}-\beta_{13} \ln \left(\text { Volatility }_{i j t}\right)+\alpha_{i t}+v_{j t}+\varepsilon_{i j t}
\end{gathered}
$$

where the explained variable $X_{\mathrm{ijt}}$ denotes exports from the reporter to the partner country. Please find the other variable descriptions in Table 3.

Table 3: Variable

\begin{tabular}{ll}
\hline Variable & Description \\
\hline$Y_{i t}$ & Nominal GDP of the reporter \\
$Y_{j t}$ & Nominal GDP of the partner \\
$Y_{\mathrm{it}} / \mathrm{Pop}_{\mathrm{it}}$ & Nominal GDP per capita of the reporter \\
$\mathrm{Y}_{\mathrm{jt}} / \mathrm{Pop}_{\mathrm{jt}}$ & Nominal GDP per capita of the partner \\
Dist $_{\mathrm{ij}}$ & Distance between capitals of reporter and partner \\
$\mathrm{EU}_{\mathrm{ijt}}$ & Dummy whether (1) or not (0) reporter and partner are member of the EU \\
EURO $_{\mathrm{ijt}}$ & Dummy whether (1) or not (0) reporter and partner have the Euro as a common currency \\
Border $_{\mathrm{ij}}$ & Dummy whether (1) or not (0) reporter and partner share a common border \\
Language $_{\mathrm{ij}}$ & Dummy whether (1) or not (0) reporter and partner share a common official language \\
Landlocked $_{\mathrm{i}}$ & Dummy whether (1) or not (0) the reporter is landlocked \\
Island $_{\mathrm{i}}$ & Dummy whether (1) or not (0) the reporter is located on an island \\
Colony $_{\mathrm{ij}}$ & Dummy whether (1) or not (0) the reporter is landlocked \\
Volatility $_{\mathrm{ijt}}$ & Bilateral volatility measure for reporter and partner \\
Zhat & Linear prediction of exports down-weighted by its standard error \\
IMR & Inverse Mills Ratio \\
\hline
\end{tabular}

A widely accepted treatment for the problems arising from zero trade flows os delivered by Helpman et al. (2008) and also employed in this study: a two stage estimation including a Probit on the likelihood that two countries trade (extensive margin), followed by a FGLS and a fixed-effects estimation of the gravity equation to quantify the volume (intensive margin). The Inverse Mills Ratio to control for sample selection bias and the linear prediction of exports down-weighted by its standard error as proxy for firm heterogeneity are then included in the second stage regression. Due to the small size of transaction costs, most authors (e.g. Mongelli \& Vega (2006) find the intensive margin to be dominating the overall effect on trade. 
The first step estimation then is:

$$
\begin{gathered}
P_{i j t}=\beta_{0}+\beta_{1} \ln \left(Y_{i t}\right)+\beta_{2} \ln \left(Y_{j t}\right)+\beta_{3} \ln \left(\frac{Y_{i t}}{\text { Pop }_{i t}}\right)+\beta_{4} \ln \left(\frac{Y_{j t}}{\text { Pop }_{j t}}\right)- \\
\beta_{5} \ln \left(\text { Distance }_{i j}\right)+\beta_{6} \text { EU }_{i j t}+\beta_{7} \text { Euro }_{i j t}+\beta_{8} \text { Border }_{i j}+\beta_{9} \text { Language }_{i j}- \\
\beta_{10} \text { Landlocked }_{i}+\beta_{11} \text { Island }_{i}+\beta_{12} \text { Colony }_{i j}-\beta_{13} \ln \left(\text { Volatility }_{i j t}\right)+\alpha_{i t}+v_{j t}+\varepsilon_{i j t}
\end{gathered}
$$

followed by the second step:

$$
\begin{gathered}
\ln X_{i j t}=\beta_{0}+\beta_{1} \ln \left(Y_{i t}\right)+\beta_{2} \ln \left(Y_{j t}\right)+\beta_{3} \ln \left(\frac{Y_{i t}}{\text { Pop }_{i t}}\right)+\beta_{4} \ln \left(\frac{Y_{j t}}{\text { Pop }_{j t}}\right)- \\
\beta_{5} \ln \left(\text { Distance }_{i j}\right)+\beta_{6} \text { EU }_{i j t}+\beta_{7} \text { Euro }_{i j t}+\beta_{8} \text { Border }_{i j}+\beta_{9} \text { Lang }_{i j} \beta_{10} \text { Landlocked }_{i}- \\
+\beta_{11} \text { Island }_{i}-\beta_{12} \ln \left(\text { Volatility }_{i j t}\right)+\beta_{13} \text { ZHAT }+\beta_{14} \text { IMR }+\alpha_{i t}+v_{j t}+\varepsilon_{i j t}
\end{gathered}
$$

The monthly trade data shows strong seasonal effects for several industries (Figure 2), thus we need to control for seasonal differences over the year. As described by Baldwin \& Taglioni (2006), in a gravity equation it is necessary for control for country specific effects over time. We do so by introducing the respective dummies to control for seasonality, differences between product categories and time and country specific effects (Table 4).

Table 4: Control Variables

\begin{tabular}{ll}
\hline Effect & Control Dummies \\
\hline Seasonality & Dummy for each month of the year \\
Product heterogeneity & Dummy for each BEC product category \\
Time and country specific effects & Dummy for each reporter and partner per year \\
\hline
\end{tabular}

\section{Results}

The empirical results for the aggregate regressions (Table 5) show a highly significant negative effects of exchange rate volatility on trade on exports for both time periods with a very similar extent for both fixed- and random-effects regressions (Equation 1). The effects remains when controls for heterogeneity and sample selection bias are included (Equation 3), but is slightly lower. In the first step probit regressions (Equation 2) volatility has a significant positive effect.

The EU dummy has a significant positive impact on exports that is lower in the second period ${ }^{7}$. The results change only slightly in the second step of the two stage approach. In the first step probit

7 Due to the fact that no countries joined the EU during the first period and thus there is now variation in the variable over time, the EU dummy gets dropped from the fixed-effects regressions. 
regression. The EU dummy has a negative sign in the first period and a positive sign in second period and is significant in both periods.

For the Euro dummy, estimation results are very different in both periods. In the first period, the effects are very low and negative besides the probit regression where the effect is significant positive and has a much higher extent. In the second period, the estimates are significant positive for all regressions.

The Estimations for different product categories (Table 6) differ in their results. While results for the EU dummy differ only slightly, the Euro dummy have a significant negative effect on exports of capital goods and a significant positive effect for the other goods. The effects for intermediates is about double the effect for final goods. Only the probit regressions show similar estimates for all three groups.

Our volatility measure has similar and significant negative effects on exports for capital goods and intermediates, but very small and insignificant effects for final goods. Results for the first step probit regressions are positive and significant and have similar size for all the product categories..

The controls for cultural or geographical ties are significant in almost all cases and have the expected sign. Only the island dummy sometimes being negative is usually not expected. The differences between fixed-effects and random-effects regressions are always very small. The coefficients have for all variables very similar significance levels, signs and extent.

\section{Findings}

According to our regression results, if both countries join the EU, bilateral trade ceteris paribus rises significantly in terms of volume or the intensive margin. The likelihood for the two EU members to trade with each other (or extensive margin) however, decreases. Only for aggregated trade in the later period we find a relatively small increase in the likelihood to trade.

If two countries have the Euro as a common currency, the likelihood to trade with each other increases for all three types goods and both periods, but is much weaker in the second period. The volume for the bilateral trade of two Euro members is negative in the first period and positive in the second period. This suggests that the Euro members needed some time to get used to and to exploit the advantages of the common currency or that it stabilized trade in the later financial crises. Trade in capital goods though does not profit from the common currency. 
An increase in volatility of the bilateral nominal exchange rate on the hand increases in all cases the likelihood for two countries to trade. The volume on the other hand decreases. Only for final goods the effect is very small and insignificant. This may be due to higher competition in capital goods and intermediates. The additional business risk caused by exchange rate uncertainty could be the reason for companies to lower their export activities.

The fact that final goods don't see a significant negative effect might be due to the usual time frame of contracts in that particular field as out volatility measure only takes into account the volatility of the past six month. If the decision whether or not to export was made long before, the effect should be limited. Another explanation would be that the decision to export was made very promptly to the conduct of the payment. The latter explanation seems more convincing as capital goods and intermediates can be expected have longer timeframes between contracting and payment. Thus, uncertainty from exchange rate fluctuations would be less threatening for firms exporting final goods as the uncertainty of a smaller period affects the exports is easier to predict and cheaper to hedge via forward markets.

The smaller size of the coefficients in the second period for the EU dummy is probably due to new members joining the EU in $2007^{\circ}$. This would indicate, that the new EU members did not benefit from the EU membership to a similar extent or the positive effect for the old EU members diminished probably due to increasing competition with the new member states.

\section{Conclusion}

As many previous studies before, we do not find unambiguous results for exchange rate volatility or Euro membership. Instead, we find significant evidence for sectoral differences in the responsiveness of bilateral trade to exchange volatility and both countries having the Euro as a common currency. Results for a EU membership of two countries in our sample is much more clear-cut and positive.

The introduction of controls for firm heterogeneity and sample selection bias only very slightly affected the results. Extensive and intensive margin show very different effects on trade.

With many Middle and Eastern European countries being new members or about to join the Euro, it will be interesting to see the specific effects on trade they are facing in the years to come.

8 From our sample, in January 2007 the Czech Republic, Estonia, Hungary, Poland, Slovakia and Slovenia joined the EU. 


\section{Bibliography}

Bacchetta, P., \& van Wincoop, E. (2000). Does Exchange-Rate Stability Increase Trade and Welfare? American Economic Review, 90(5), 1093 - 1109.

Bahmani-Oskooee, M., \& Hegerty, S. W. (2007). Exchange rate volatility and trade flows: a review article. Journal of Economic Studies, 34(3), 211 - 255.

Baldwin, R., \& Krugman, P. (1989). Persistent Trade Effects of Large Exchange Rate Shocks. The Quarterly Journal of Economics, 104(4), 635 - 54.

Baldwin, R., \& Taglioni, D. (2006). Gravity for Dummies and Dummies for Gravity Equations. CEPR Discussion Papers, 5850.

Barkoulas, J.T., Baum, C.F., \& Caglayan, M. (2002). Exchange rate effects on the volume and variability of trade flows. Journal of International Money and Finance, 21(4), 481-496.

Barkoulas, John T., Baum, Christopher F., \& Caglayan, Mustafa. (2002). Exchange rate effects on the volume and variability of trade flows. Journal of International Money and Finance, 21(4), $481-496$.

Baron, D. P. (1976). Fluctuating Exchange Rates and the Pricing of Exports. Economic Inquiry, 14(3), $425-38$.

Baum, Christopher F., \& Hristakeva, S. (2001). DENTON: Stata module to interpolate a flow or stock series from low-frequency totals via proportional Denton method.

Baum, Christopher F., Caglayan, Mustafa, \& Ozkan, N. (2004). Nonlinear effects of exchange rate volatility on the volume of bilateral exports. Journal of Applied Econometrics, 19(1), 1 - 23.

Broll, U., \& Eckwert, B. (1999). Exchange Rate Volatility and International Trade. Southern Economic Journal, 66(1), $178-18$.

Clark, P. B. (1973). Uncertainty, exchange risk, and the level of international trade. Economic Inquiry, 11(3), 302-313.

Clark, P., Tamirisa, N., Wei, S.-J., Sadikov, A., \& Zeng, L. (2004). Exchange Rate Volatility and Trade Flows - Some New Evidence. International Monetary Fund Occasional Paper, No. 235. Occasional Paper No. 235. 
Cotter, J., \& Bredin, D. (2011). Real and Nominal Foreign Exchange Volatility Effects on Exports The Importance of Timing.

Côté, A. (1994). Exchange Rate Volatility and Trade: A Survey. EconWPA, 9406001.

Ćorić, B., \& Pugh, G. (2010). The effects of exchange rate variability on international trade: a metaregression analysis. Applied Economics, 42(20), 2631 - 2644.

Dell'Ariccia, G. (1999). Exchange rate fluctuations and trade flows: evidence from the European Union. IMF Staff Papers, 46(3), 315-334. JSTOR.

Franke, G. (1991). Exchange rate volatility and international trading strategy. Journal of International Money and Finance, 10(2), $292-307$.

Helpman, E., Melitz, M., \& Rubinstein, Y. (2008). Estimating Trade Flows: Trading Partners and Trading Volumes. The Quarterly Journal of Economics, 123(2), 441 - 487.

McKenzie, M. D. (1999). The Impact of Exchange Rate Volatility on International Trade Flows. Journal of Economic Surveys, 13(1), 71 - 106.

Mongelli, F. P., \& Vega, J. L. (2006). What Effects is EMU Having on the Euro Area and Its Member Countries?: An Overview. Social Science Research. European Central Bank.

Ozturk, I. (2006). Exchange Rate Volatility and Trade: A Literature Survey. International Journal of Applied Econometrics and Quantitative Studies, 3(1).

Rose, A. K. (2000). One Currency, One Market: Estimating the Effect of Common Currencies on Trade. Economic Policy, 15(30), 7-46.

Sercu, P., \& Vanhulle, C. (1992). Exchange rate volatility, international trade, and the value of exporting firms. Journal of Banking \& Finance, 16(1), 155 - 182.

Tenreyro, S. (2007). On the trade impact of nominal exchange rate volatility. Journal of Development Economics, 82(2), 485-508.

United Nations Department of Economic and Social Affairs. (2007). Future revision of the Classification by Broad Economic Categories (BEC).

Viaene, J.-M., \& de Vries, C. G. (1992). International trade and exchange rate volatility. European Economic Review, 36(6), 1311 - 1321. 
Wang, K.-L., \& Barrett, C. B. (2007). Estimating the Effects of Exchange Rate Volatility on Export Volumes. Journal of Agricultural and Resource Economics, 32(02).

Wei, S.-J. (1999). Currency hedging and goods trade. European Economic Review, 43(7), 1371 1394. 


\section{Appendix}

Table 5: Aggregate regressions by time period

\begin{tabular}{|c|c|c|c|c|c|c|c|c|c|c|c|}
\hline & $\mathrm{FE}$ & RE & Probit & FE & RE & & FE & RE & Probit & FE & RE \\
\hline$Y_{i t}$ & $\begin{array}{c}0.523^{* * *} \\
(0.05)\end{array}$ & $\begin{array}{c}0.522^{* * *} \\
(0.05)\end{array}$ & $\begin{array}{c}0.226^{* * *} \\
(0.074)\end{array}$ & $\begin{array}{c}0.531^{* * *} \\
(0.05)\end{array}$ & $\begin{array}{c}0.532^{* * *} \\
(0.05)\end{array}$ & $Y_{i t}$ & $\begin{array}{c}-6.277^{* * *} \\
(0.757)\end{array}$ & $\begin{array}{c}-6.272^{* * *} \\
(0.757)\end{array}$ & $\begin{array}{c}-3.799 * * * \\
(1.188)\end{array}$ & $\begin{array}{c}-5.757^{* * *} \\
(0.758)\end{array}$ & $\begin{array}{c}-5.843^{* * *} \\
(0.758)\end{array}$ \\
\hline$Y_{j t}$ & $\begin{array}{c}0.645^{* * *} \\
(0.049)\end{array}$ & $\begin{array}{c}0.646^{* * *} \\
(0.049)\end{array}$ & $\begin{array}{r}0.184^{* *} \\
(0.081)\end{array}$ & $\begin{array}{c}0.654^{* * *} \\
(0.049)\end{array}$ & $\begin{array}{c}0.657 * * * \\
(0.049)\end{array}$ & $Y_{j t}$ & $\begin{array}{c}-1.420^{*} \\
(0.75)\end{array}$ & $\begin{array}{c}-1.430^{*} \\
(0.751)\end{array}$ & $\begin{array}{c}0.5 \\
(1.224)\end{array}$ & $\begin{array}{l}-0.544 \\
(0.753)\end{array}$ & $\begin{array}{l}-0.658 \\
(0.753)\end{array}$ \\
\hline $\mathrm{Y}_{\mathrm{it}} / \mathrm{Pop}_{\mathrm{it}}$ & $\begin{array}{l}-0.004 \\
(0.006)\end{array}$ & $\begin{array}{l}-0.004 \\
(0.006)\end{array}$ & $\begin{array}{l}-0.006 \\
(0.01)\end{array}$ & $\begin{array}{l}-0.004 \\
(0.006)\end{array}$ & $\begin{array}{l}-0.004 \\
(0.006)\end{array}$ & $Y_{i t} / P p_{i t}$ & $\begin{array}{c}7.235^{* * *} \\
(0.752)\end{array}$ & $\begin{array}{c}7.229 * * * \\
(0.753)\end{array}$ & $\begin{array}{c}3.743^{* * *} \\
(1.179)\end{array}$ & $\begin{array}{c}6.738^{* * *} \\
(0.753)\end{array}$ & $\begin{array}{c}6.821^{* * *} \\
(0.753)\end{array}$ \\
\hline$Y_{j \mathrm{t}} / \mathrm{Pop}_{\mathrm{jt}}$ & $\begin{array}{l}0.011^{*} \\
(0.006)\end{array}$ & $\begin{array}{l}0.011^{*} \\
(0.006)\end{array}$ & $\begin{array}{c}-0.008 \\
(0.012)\end{array}$ & $\begin{array}{c}0.01 \\
(0.006)\end{array}$ & $\begin{array}{c}0.01 \\
(0.006)\end{array}$ & $Y_{j t} / P o p_{j t}$ & $\begin{array}{c}2.935^{* * *} \\
(0.744)\end{array}$ & $\begin{array}{c}2.940^{* * *} \\
(0.745)\end{array}$ & $\begin{array}{c}0.12 \\
(1.219)\end{array}$ & $\begin{array}{c}2.123^{* * *} \\
(0.747)\end{array}$ & $\begin{array}{c}2.225^{* * *} \\
(0.747)\end{array}$ \\
\hline Distance $_{\mathrm{ij}}$ & - & $\begin{array}{c}-1.365^{* * *} \\
(0.046)\end{array}$ & $\begin{array}{c}-0.884^{* * *} \\
(0.007)\end{array}$ & - & $\begin{array}{c}-1.416^{* * *} \\
(0.045)\end{array}$ & Distance $_{\mathrm{ij}}$ & - & $\begin{array}{c}-1.375^{* * *} * \\
(0.046)\end{array}$ & $\begin{array}{c}-0.898 * * * \\
(0.007)\end{array}$ & - & $\begin{array}{c}-1.470 * * * \\
(0.045)\end{array}$ \\
\hline$E U_{i j t}$ & - & $\begin{array}{c}0.379 * * * \\
(0.079)\end{array}$ & $\begin{array}{c}-1.249 * * * \\
(0.041)\end{array}$ & - & $\begin{array}{c}0.337^{* * *} \\
(0.079)\end{array}$ & $\mathrm{EU}_{\mathrm{ijt}}$ & $\begin{array}{c}0.208^{* * *} \\
(0.034)\end{array}$ & $\begin{array}{c}0.212^{* * *} \\
(0.034)\end{array}$ & $\begin{array}{c}0.139 * * * \\
(0.053)\end{array}$ & $\begin{array}{c}0.201^{* * *} \\
(0.034)\end{array}$ & $\begin{array}{c}0.202^{* * *} \\
(0.034)\end{array}$ \\
\hline Euro $_{\mathrm{ijt}}$ & $\begin{array}{c}-0.031 * * * \\
(0.012)\end{array}$ & $\begin{array}{c}-0.028 * * \\
(0.012)\end{array}$ & $\begin{array}{c}0.671^{* * *} \\
(0.013)\end{array}$ & $\begin{array}{c}-0.026^{* *} \\
(0.012)\end{array}$ & $\begin{array}{c}-0.021^{*} \\
(0.012)\end{array}$ & Euro $_{\mathrm{ijt}}$ & $\begin{array}{c}0.130^{* * *} \\
(0.014)\end{array}$ & $\begin{array}{c}0.133^{* * *} \\
(0.013)\end{array}$ & $\begin{array}{c}0.200 * * * \\
(0.009)\end{array}$ & $\begin{array}{c}0.144^{* * *} \\
(0.014)\end{array}$ & $\begin{array}{c}0.145^{* * *} \\
(0.014)\end{array}$ \\
\hline Border $_{i j}$ & - & $\begin{array}{c}0.774 * * * \\
(0.077)\end{array}$ & $\begin{array}{c}0.803^{* * *} \\
(0.015)\end{array}$ & - & $\begin{array}{c}0.805^{* * *} \\
(0.075)\end{array}$ & Border $_{i j}$ & - & $\begin{array}{c}0.889 * * * \\
(0.076)\end{array}$ & $\begin{array}{c}0.737^{* * *} \\
(0.015)\end{array}$ & - & $\begin{array}{c}0.937^{* * *} \\
(0.074)\end{array}$ \\
\hline Language $_{\mathrm{ij}}$ & - & $\begin{array}{c}0.449 * * * \\
(0.096)\end{array}$ & $\begin{array}{c}0.356^{* * *} \\
(0.015)\end{array}$ & - & $\begin{array}{c}0.482^{* * *} \\
(0.095)\end{array}$ & Language $_{\mathrm{ij}}$ & - & $\begin{array}{c}0.515^{* * *} \\
(0.095)\end{array}$ & $\begin{array}{c}0.267^{* * *} \\
(0.015)\end{array}$ & - & $\begin{array}{c}0.568^{* * *} \\
(0.094)\end{array}$ \\
\hline Colony $_{\mathrm{ij}}$ & - & $\begin{array}{r}0.199 * * \\
(0.092)\end{array}$ & $\begin{array}{l}-0.016 \\
(0.017)\end{array}$ & - & - & Colony $_{\mathrm{ij}}$ & - & $\begin{array}{c}0.343^{* * *} \\
(0.091)\end{array}$ & $\begin{array}{c}0.166 * * * \\
(0.018)\end{array}$ & - & \\
\hline Island $_{i}$ & - & $\begin{array}{c}-0.787^{* * *} \\
(0.196)\end{array}$ & $\begin{array}{c}-0.435 * * \\
(0.178)\end{array}$ & - & $\begin{array}{c}-0.835^{* * *} \\
(0.194)\end{array}$ & Island $_{i}$ & - & $\begin{array}{c}-11.294^{* * *} \\
(1.227)\end{array}$ & $\begin{array}{c}-7.181 * * * \\
(1.913)\end{array}$ & - & $\begin{array}{c}-10.830 * * * \\
(1.227)\end{array}$ \\
\hline Landlocked $_{i}$ & - & $\begin{array}{c}-4.133^{* * *} \\
(0.403)\end{array}$ & $\begin{array}{c}-1.954 * * * \\
(0.464)\end{array}$ & - & $\begin{array}{c}-4.283^{* * *} \\
(0.398)\end{array}$ & Landlocked $_{i}$ & - & $\begin{array}{c}-34.568 * * * \\
(3.769)\end{array}$ & $\begin{array}{c}-16.280 * * * \\
(6.223)\end{array}$ & - & $\begin{array}{c}-30.642^{* * *} \\
(3.783)\end{array}$ \\
\hline Volatility $_{\mathrm{ijt}}$ & $\begin{array}{c}-0.019 * * * \\
(0.006)\end{array}$ & $\begin{array}{c}-0.018^{* * *} \\
(0.006)\end{array}$ & $\begin{array}{c}0.101^{* * *} \\
(0.007)\end{array}$ & $\begin{array}{c}-0.016 * * * \\
(0.006)\end{array}$ & $\begin{array}{c}-0.015^{* * *} \\
(0.006)\end{array}$ & Volatility $_{\mathrm{ijt}}$ & $\begin{array}{c}-0.023^{* * *} \\
(0.005)\end{array}$ & $\begin{array}{c}-0.023 * * * \\
(0.005)\end{array}$ & $\begin{array}{c}0.022^{* * *} \\
(0.007)\end{array}$ & $\begin{array}{c}-0.013^{* *} \\
(0.005)\end{array}$ & $\begin{array}{c}-0.014^{* * *} \\
(0.005)\end{array}$ \\
\hline Zhat & - & - & - & $\begin{array}{c}-0.005^{* * *} \\
(0.002)\end{array}$ & $\begin{array}{c}-0.007 * * * \\
(0.001)\end{array}$ & Zhat & - & - & - & $\begin{array}{c}-0.036^{* * *} \\
(0.003)\end{array}$ & $\begin{array}{c}-0.031 * * * \\
(0.002)\end{array}$ \\
\hline IMR & - & - & - & $\begin{array}{c}1.506^{* * *} \\
(0.143)\end{array}$ & $\begin{array}{c}1.724^{* * *} \\
(0.13)\end{array}$ & IMR & - & - & - & $\begin{array}{c}0.323 \\
(0.255)\end{array}$ & $\begin{array}{c}0.929 * * * \\
(0.209)\end{array}$ \\
\hline Obs. & 739373 & 739373 & 944091 & 739373 & 739373 & Obs. & 853359 & 853359 & 1046520 & 853359 & 853359 \\
\hline $\mathbf{R}^{2}$ & 0.037 & 0.6324843 & - & 0.038 & 0.6327548 & $\mathbf{R}^{2}$ & 0.028 & 0.6113477 & - & 0.028 & 0.6124176 \\
\hline RMSE & 1.011396 & 1.011878 & - & 1.011312 & 1.011823 & RMSE & 1.065978 & 1.066784 & - & 1.065872 & 1.066712 \\
\hline
\end{tabular}




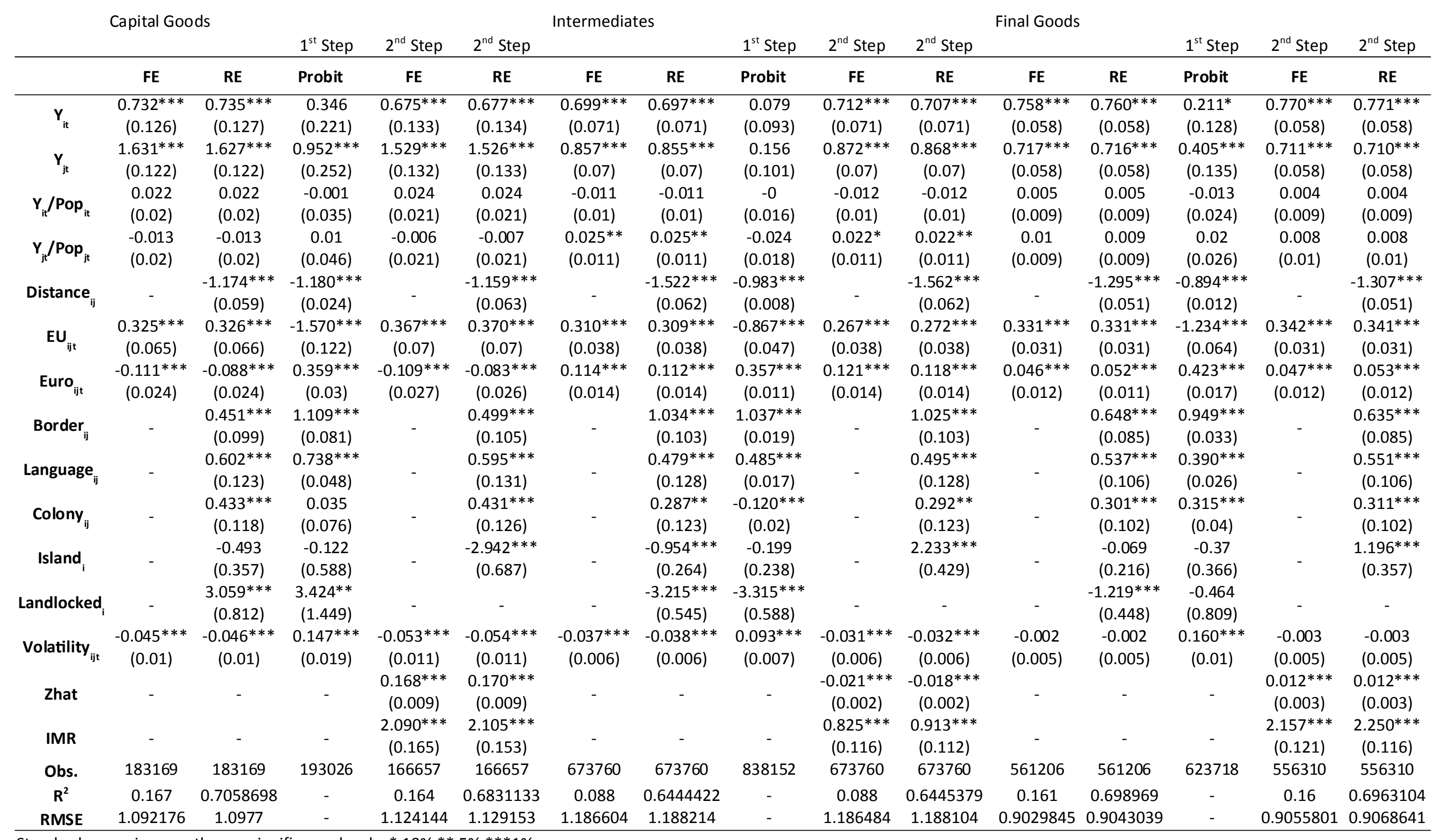

Standard errors in parentheses; significance levels: * $10 \% * * 5 \% * * * 1 \%$ 


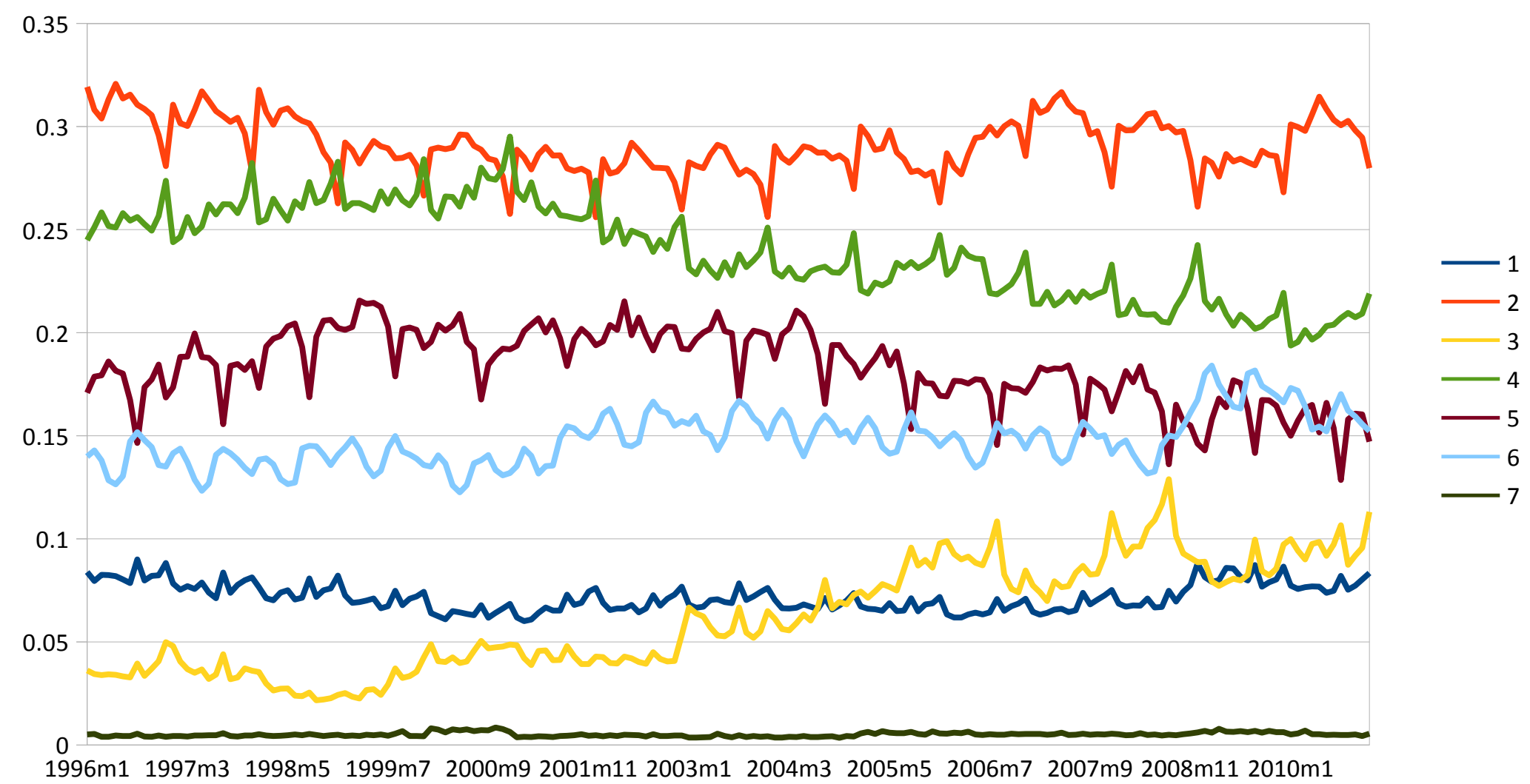


Figure 2: Share of total exports by BEC category, 1996-2010

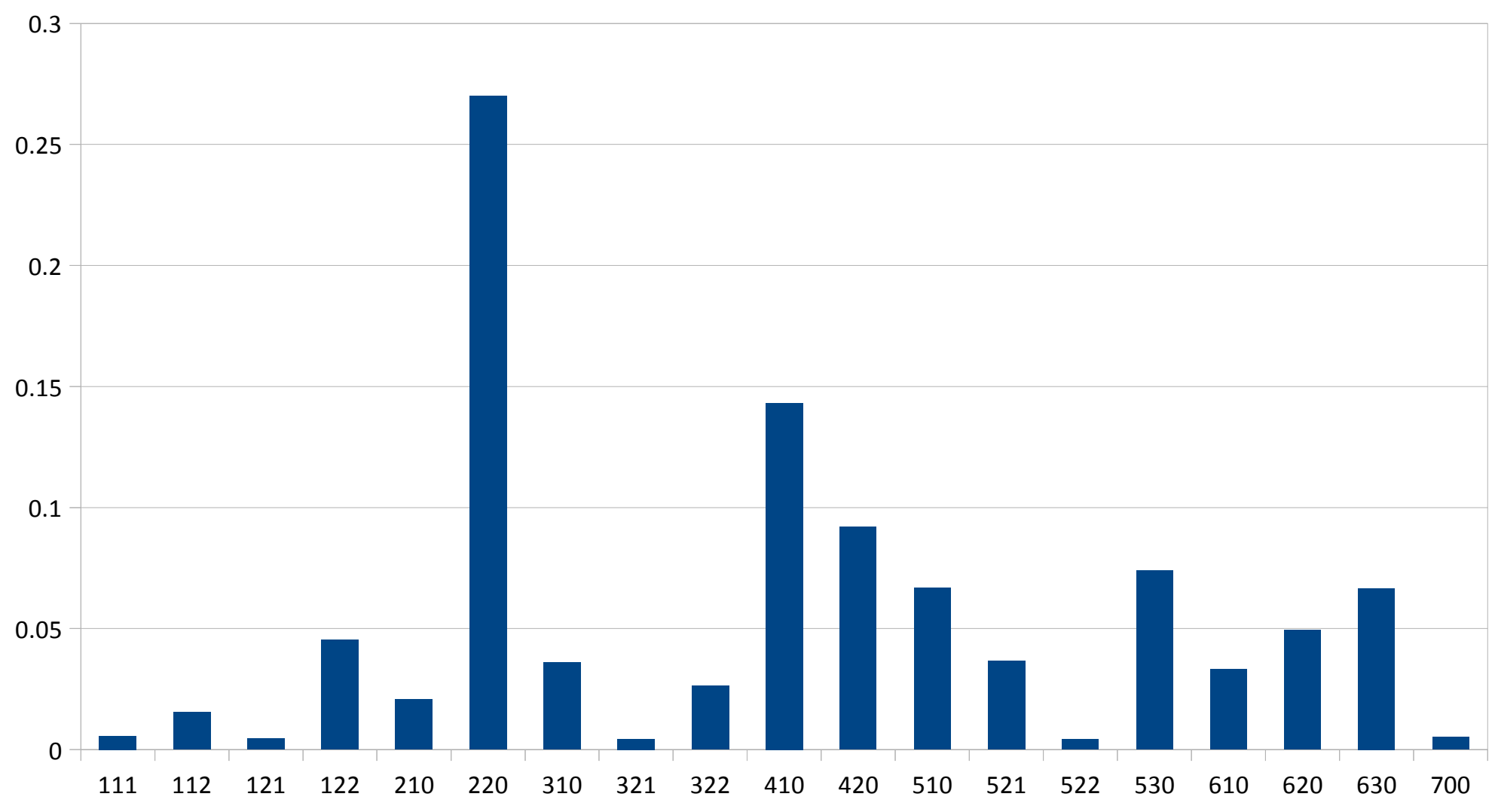

